\title{
Bactericidal Effect of Photodynamic Therapy, Alone or in Combination with Mupirocin or Linezolid, on Staphylococcus aureus
}

\section{OPEN ACCESS}

Edited by:

Octavio Luiz Franco,

Universidade Católica de Brasilia,

Brazil

Reviewed by:

Anna V. Sharikova,

University at Albany (SUNY),

United States

Valdir Carlos Colussi,

UH Seidman Case Medical Center,

United States

*Correspondence:

Vanesa Pérez-Laguna

565686@unizar.es

${ }^{\dagger}$ These authors have contributed equally to this work.

Specialty section:

This article was submitted to Antimicrobials, Resistance and

Chemotherapy,

a section of the journa

Frontiers in Microbiology

Received: 05 April 2017

Accepted: 18 May 2017

Published: 31 May 2017

Citation:

Pérez-Laguna V, Pérez-Artiaga L, Lampaya-Pérez V, García-Luque I,

Ballesta S, Nonell S,

Paz-Cristobal MP, Gilaberte $Y$ and Rezusta A (2017) Bactericidal Effect of

Photodynamic Therapy, Alone or in

Combination with Mupirocin or Linezolid, on Staphylococcus aureus.

Front. Microbiol. 8:1002.

doi: 10.3389/fmicb.2017.01002

\begin{abstract}
Vanesa Pérez-Laguna ${ }^{1,2 *}$, Luna Pérez-Artiaga ${ }^{2}$, Verónica Lampaya-Pérez ${ }^{2}$, Isabel García-Luque ${ }^{3}$, Sofía Ballesta ${ }^{3}$, Santi Nonell ${ }^{4}$, Manuel P. Paz-Cristobal ${ }^{1}$, Yolanda Gilaberte ${ }^{1,5+}$ and Antonio Rezusta ${ }^{1,2,6+}$

${ }^{1}$ IIS Aragón, Zaragoza, Spain, ${ }^{2}$ Department of Microbiology, Hospital Universitario Miguel Servet, Zaragoza, Spain, ${ }^{3}$ Department of Microbiology, University of Sevilla, Seville, Spain, ${ }^{4}$ Institut Químic de Sarrià, Universitat Ramon Llull, Barcelona, Spain, ${ }^{5}$ Department of Dermatology, Hospital San Jorge, Huesca, Spain, ${ }^{6}$ Department of Microbiology, Preventive Medicine and Public Health, University of Zaragoza, Zaragoza, Spain
\end{abstract}

Antibiotic treatments frequently fail due to the development of antibiotic resistance, underscoring the need for new treatment strategies. Antimicrobial photodynamic therapy (aPDT) could constitute an alternative therapy. In bacterial suspensions of Staphylococcus aureus, which is commonly implicated in cutaneous and mucosal infections, we evaluated the in vitro efficacy of aPDT, using the photosensitizing agents rose bengal $(\mathrm{RB})$ or methylene blue $(\mathrm{MB})$, alone or combined with the antibiotics mupirocin (MU) or linezolid (LN). RB or MB, at concentrations ranging from 0.03 to 10 $\mu \mathrm{g} / \mathrm{ml}$, were added to $S$. aureus ATCC 29213 suspensions containing $>10^{8} \mathrm{cells} / \mathrm{ml}$, in the absence or presence of $\mathrm{MU}$ or $\mathrm{LN}(1$ or $10 \mu \mathrm{g} / \mathrm{ml})$. Suspensions were irradiated with a white metal halide $(\lambda 420-700 \mathrm{~nm}$ ) or light-emitting diode lamp ( $\lambda 515$ and $\lambda 625 \mathrm{~nm}$ ), and the number of viable bacteria quantified by counting colony-forming units (CFU) on blood agar. Addition of either antibiotic had no significant effect on the number of CFU/ml. By contrast, RB-aPDT and MB-aPDT effectively inactivated $S$. aureus, as evidenced by a $6 \log _{10}$ reduction in bacterial growth. In the presence of $M U$ or $L N$, the same $6 \log _{10}$ reduction was observed in response to aPDT, but was achieved using significantly lower concentrations of the photosensitizers RB or MB. In conclusion, the combination of $\mathrm{MU}$ or $L N$ and RB/MB-aPDT appears to exert a synergistic bactericidal effect against $S$. aureus in vitro.

Keywords: S. aureus, antibiotics, rose Bengal, methylene blue, photoinactivation

\section{INTRODUCTION}

Microbial infections are a leading causes of mortality worldwide, largely due to the development of multidrug resistance (Livermore, 2009). In hospitals, Staphylococcus aureus, a Gram-positive bacteria, has become the most commonly isolated pathogen involved in serious diseases (Emori and Gaynes, 1993), and the emergence of methicillin-resistant S. aureus (MRSA) strains worldwide poses serious risks to patients with immunological diseases (Orrett and Land, 2006; Boucher et al., 2009). Several antibiotics, including mupirocin (MU) and linezolid (LN), have proven effective 
against both methicillin-resistant and non-resistant strains of $S$. aureus (Tallón et al., 2002; Larru et al., 2016). MU is one of the most frequently used antibiotics for topical treatment of $S$. aureus skin infections (Saderi et al., 2008), while LN is more commonly administered intravenously (Cattaneo et al., 2013).

Although results vary depending on the studied strain and its geographical localization, several recent studies suggest that the antibiotic resistance of $S$. aureus is on the rise, underscoring the need for new treatment strategies (Orrett, 2008; Saderi et al., 2008; Gu et al., 2013; Gostev et al., 2015; Larru et al., 2016).

Antimicrobial photodynamic therapy (aPDT) is based on the use of photosensitizer molecules that are activated by harmless visible light in the presence of oxygen. This combination generates reactive oxygen species that can oxidize many biological molecules, including proteins, nucleic acids, and lipids, leading to cell death (Henderson and Dougherty, 1992). Given the rapid and selective union that forms between photosensitizers and the cells of microorganisms, aPDT has been proposed as an alternative treatment for localized infections (Dai et al., 2012).

Phenothiazinium derivates and fluorescein-like molecules, such as methylene blue (MB) and rose bengal (RB), respectively, are polycyclic aromatic molecules that have been used as photosensitizers in aPDT, demonstrating the efficacy of this approach in inactivating resistant forms of bacteria that are not easily killed by conventional antibiotics. Initial in vitro studies have produced promising results, supporting the use of these compounds in the treatment of microbial infections (Demidova and Hamblin, 2005; Tanaka et al., 2012). The combination aPDT and conventional antibiotics to treat staphylococcal infections has also shown significant potential, opening up new avenues in the quest for novel therapies for these dangerous and recurrent infections (Di Poto et al., 2009; Sbarra et al., 2009).

The aim of this study was to compare the in vitro efficacy of aPDT using the photosensitizers RB or MB (RB-aPDT and MB-aPDT), combined with the antibiotics MU or LN, against $S$. aureus.

\section{MATERIALS AND METHODS}

\section{Chemicals and Media}

- Solvent: Bidistilled water.

- Culture Media: Columbia blood agar (BA) (Oxoid ${ }^{\circledR}$; Madrid, Spain).

- Antibiotics: Mupirocin (MU) and linezolid (LN), both from Sigma-Aldrich ${ }^{\circledR}$ (Madrid, Spain). Both antibiotics were applied at concentrations of $1 \mu \mathrm{g} / \mathrm{ml}$ and $10 \mu \mathrm{g} / \mathrm{ml}$, both of which exceed the minimum inhibitory concentration of the strain (EUCAST) but do not cause significant damage alone in $S$. aureus strains. Respective controls were performed.

- Photosensitizers: Methylene blue (MB), purchased from Sigma-Aldrich ${ }^{\circledR}$ (Madrid, Spain), and (RB), from SigmaAldrich-Fluka ${ }^{\circledR}$ (Madrid, Spain). Stock MB and RB solutions were prepared and diluted in bidistilled water immediately prior to use. All solutions were prepared and handled under light-restricted conditions. Concentrations ranged from 0.03 to $10 \mu \mathrm{g} / \mathrm{ml}$. This concentration range was chosen based on unpublished results from previous experiments performed in our laboratory using 2-fold serial dilutions from 640 to $0.03 \mu \mathrm{g} / \mathrm{ml}$ of both photosensitizers.

\section{Light Sources}

Two light-emitting diode (LED) and one white metal halide (WMH) lamps were used.

For $\mathrm{RB}$ (maximum absorption $\lambda, 557 \mathrm{~nm}$ ) and $\mathrm{MB}$ (maximum absorption $\lambda, 665 \mathrm{~nm}$ ) (Soria-Lozano et al., 2015; Figure 1) aPDT was performed using LED lamps emitting at $515 \pm 10 \mathrm{~nm}$ $\left(5.8 \mathrm{~mW} / \mathrm{cm}^{2}\right)$ and $625 \mathrm{~nm} \pm 10 \mathrm{~nm}\left(7 \mathrm{~mW} / \mathrm{cm}^{2}\right)$ (Figure 2), respectively, with fluences of $18 \mathrm{~J} / \mathrm{cm}^{2}$ and $37 \mathrm{~J} / \mathrm{cm}^{2}$.

For both photosensitizers a WMH lamp emitting at 420-700 $\mathrm{nm}$ (Soria-Lozano et al., 2015) at a fluence of $37 \mathrm{~J} / \mathrm{cm}^{2}$ was used (Figure 3). The lamp had an irradiance of $90 \mathrm{~mW} / \mathrm{cm}^{2}$. The specific irradiance values at the maximum absorption $\lambda$ of $\mathrm{RB}$ and $\mathrm{MB}$ are $292 \mu \mathrm{W} / \mathrm{cm}^{2}$ at $557 \mathrm{~nm}$ and $300 \mu \mathrm{W} / \mathrm{cm}^{2}$ at $665 \mathrm{~nm}$, respectively.

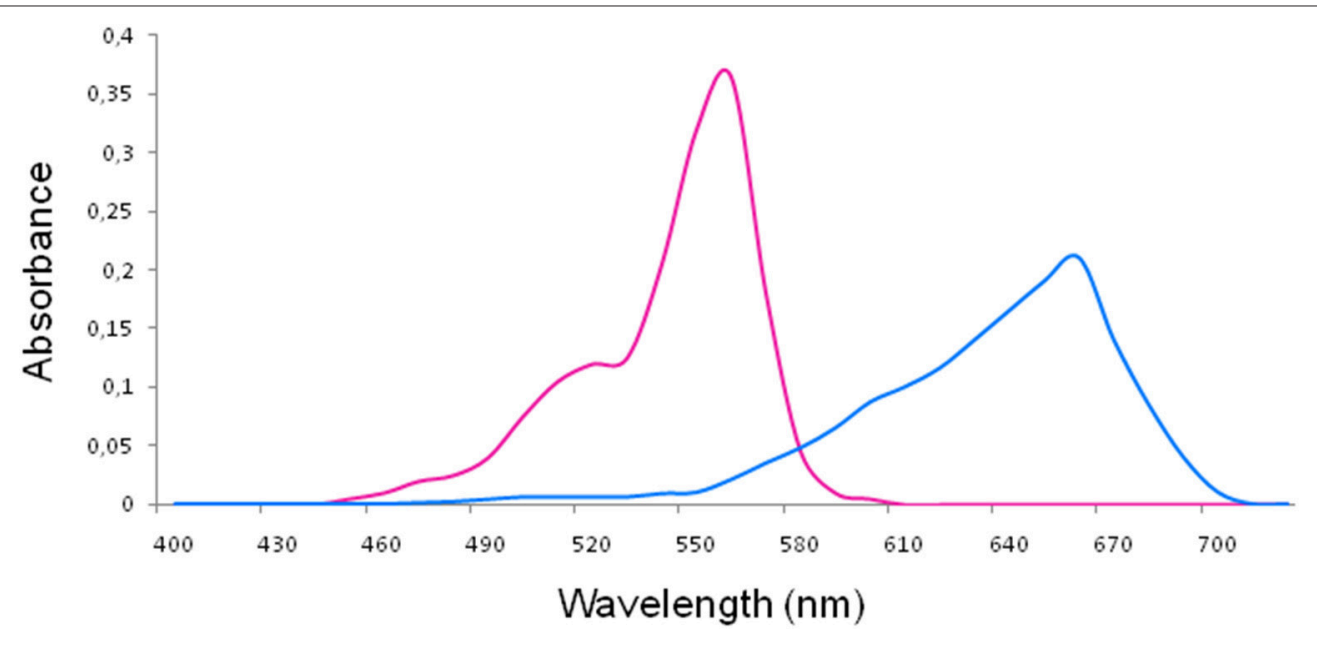

FIGURE 1 | Absorption spectra of rose bengal (left) and methylene blue (right). 


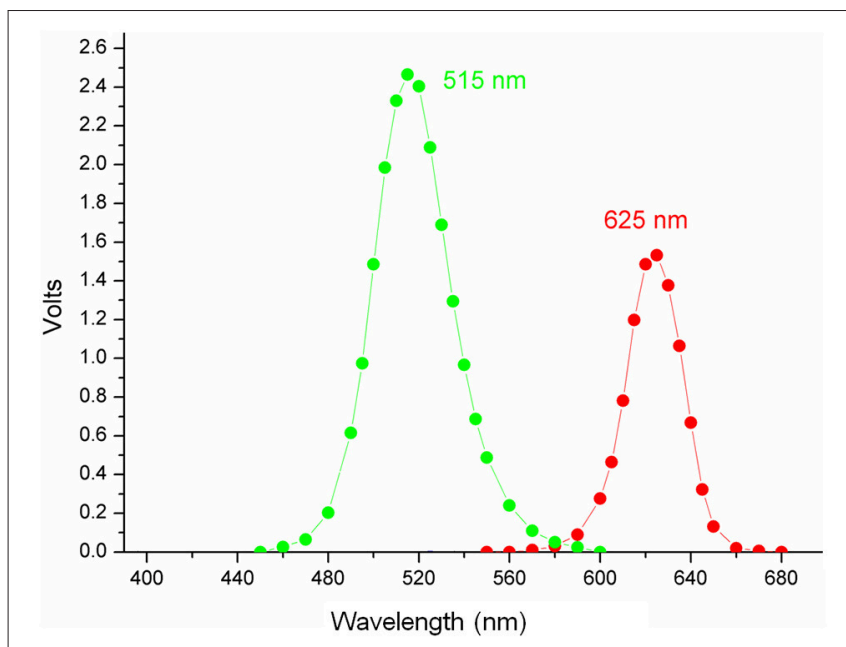

FIGURE 2 | Emission spectra of LED lamps.

\section{Microorganisms and Growth Conditions}

Staphylococcus aureus ATCC 29213 was acquired from the American Type Culture Collection (ATCC, Rockville, MD, USA). Microorganisms were grown aerobically overnight on BA plates at $35^{\circ} \mathrm{C}$. The inoculum was prepared in bidistilled water and adjusted to $0.5 \pm 0.03$ on the McFarland scale [concentrations in the range of $>10^{8}$ colony-forming units per $\left.\mathrm{ml}(\mathrm{CFU} / \mathrm{ml})\right]$. Cell viability was assessed in serial dilutions of suspension controls by counting CFU after incubation overnight at $35^{\circ} \mathrm{C}$ on BA. For aPDT assays, samples were grown on BA in the same conditions as controls.

\section{In vitro Photodynamic Treatment of Bacteria}

Bacteria seeded on $\mathrm{BA}$ were cultured overnight at $35^{\circ} \mathrm{C}$, and suspensions of the desired McFarland value ( $>10^{7} \mathrm{CFU} / \mathrm{ml}$ ) were prepared in bidistilled water and deposited into 96-well microtiter plates. Varying concentrations of the photosensitizer ( $\mathrm{RB}$ or $\mathrm{MB}$; concentration range $0.03-10 \mu \mathrm{g} / \mathrm{ml}$ ) were added, in the presence or absence of MU or LN $(1 \mu \mathrm{g} / \mathrm{ml}$ or 10 $\mu \mathrm{g} / \mathrm{ml}$ ). The final volume of each well was $100 \mu \mathrm{l}$. Irradiation proceeded with no preincubation period; the suspensions were immediately subjected to irradiation with fluences of either $18 \mathrm{~J} / \mathrm{cm}^{2}$ or $37 \mathrm{~J} / \mathrm{cm}^{2}$ using LED lamps and $37 \mathrm{~J} / \mathrm{cm}^{2}$ using the WMH lamp. Control samples were subjected to identical treatment, in the absence or presence of the photosensitizer, and were either kept in darkness or irradiated to evaluate the effect of each parameter. After completing the aPDT protocol, samples and controls were cultured on BA and incubated overnight at $35^{\circ} \mathrm{C}$. The effectiveness of aPDT treatment was assessed by counting the number of $\mathrm{CFU} / \mathrm{ml}$ using a Flash and Go automatic colony counter (IUL, S.A, Spain) and comparing the results with controls. All experiments were carried out at least 5 times. A reduction the number of $\mathrm{CFU} / \mathrm{ml}$ of $6 \log _{10}$ was considered indicative of bactericidal activity.

\section{RESULTS}

\section{Photoinactivation of Bacteria by RB-aPDT or MB-aPDT}

aPDT effectively inactivated $S$. aureus ATCC 29213, resulting in $6 \log _{10}$ reduction in bacterial growth in all assays (Table $\mathbf{1}$, Figures 4, 5).

Using $\mathrm{MB}$ as a photosensitizer, the concentration required for a bactericidal effect was $0.62 \mu \mathrm{g} / \mathrm{ml}$ at both fluences $\left(18 \mathrm{~J} / \mathrm{cm}^{2}\right.$ and $37 \mathrm{~J} / \mathrm{cm}^{2}$ ) with the 625-nm LED lamp (Figures 4D,E, 5D,E) and at $37 \mathrm{~J} / \mathrm{cm}^{2}$ with the WMH-lamp (Figures $4 \mathrm{~F}, 5 \mathrm{~F}$ ).

Using $\mathrm{RB}$ as a photosensitizer, the concentration required for a bactericidal effect was $0.62 \mu \mathrm{g} / \mathrm{ml}$ for the WMH lamp (Figures 4C, 5C), and $0.31 \mu \mathrm{g} / \mathrm{ml}$ for the 515-nm LED lamp, at fluences of either $18 \mathrm{~J} / \mathrm{cm}^{2}$ or $37 \mathrm{~J} / \mathrm{cm}^{2}$ (Figures $4 A, B, 5 A, B$ ).

\section{Bactericidal Effect of aPDT Combined with Classical Antibiotics}

The inhibitory effect of aPDT on S. aureus was maintained in the presence of 1 or $10 \mu \mathrm{g} / \mathrm{ml}$ of MU or LN, as evidenced by a $6 \log _{10}$ reduction in all assays. However, by combining aPDT with either of the two antimicrobial agents, the same reduction in bacterial growth was achieved after decreasing photosensitizer concentration by $50 \%$, except in the case of the WMH-light MB-aPDT $+1 \mu \mathrm{g} / \mathrm{ml} \mathrm{LN}$, for which no change was observed (Table 1, Figures 4, 5). The combination of $10 \mu \mathrm{g} / \mathrm{ml} \mathrm{MU}+\mathrm{RB}-$ aPDT or MB-aPDT using the WMH light allowed for the greatest decrease $(>75 \%)$ in photosensitizer concentration $(\leq 0.03 \mu \mathrm{g} / \mathrm{ml})$ with respect to the concentration required in the absence of antibiotic $(0.62 \mu \mathrm{g} / \mathrm{ml})$ (Table 1, Figures 4C,F).

In general, using the same antibiotic concentrations and irradiation conditions, an equivalent reduction in bacterial activity was achieved using lower concentrations of RB than of MB. There were 3 exceptions to this observation: $1 \mu \mathrm{g} / \mathrm{ml}$ of LN + WMH light, and both concentrations of MU + WMH light (Table 1).

MU, especially at the higher concentration $(10 \mu \mathrm{g} / \mathrm{ml})$, was more effective than $\mathrm{LN}$ in allowing a maximum decrease in the concentration of $\mathrm{RB}$ used $(0.03 \mu \mathrm{g} / \mathrm{ml})$, both at the lowest fluence $\left(18 \mathrm{~J} / \mathrm{cm}^{2}\right)$ with the 515-nm LED light and the highest fluence $\left(37 \mathrm{~J} / \mathrm{cm}^{2}\right)$ with the 515 -nm LED light and theWMH light (Table 1).

\section{Toxic Effects of Photosensitizers, Antibiotics, and Irradiation}

At the range of concentrations evaluated and in the same conditions as described for the experiments above, but keeping the samples in darkness, neither photosensitizer reduced the number of $\mathrm{CFU} / \mathrm{ml}$ in the initial inoculum.

In the absence of photosensitizers and irradiation, the tested concentrations of both antibiotics failed to effectively inactivate the bacteria. A maximum reduction of $0.2 \log _{10}$ was observed for the highest concentration of both antibiotics $(10 \mu \mathrm{g} / \mathrm{ml})$ (Figures 4, 5).

Neither the LED lamp at $18 \mathrm{~J} / \mathrm{cm}^{2}$ and $37 \mathrm{~J} / \mathrm{cm}^{2}$ nor the WMH-lamp at $37 \mathrm{~J} / \mathrm{cm}^{2}$ significantly reduced the number of $\mathrm{CFU} / \mathrm{ml}$ (reduction of $<0.2 \log _{10}$ ) (Figures 4,5$)$. 


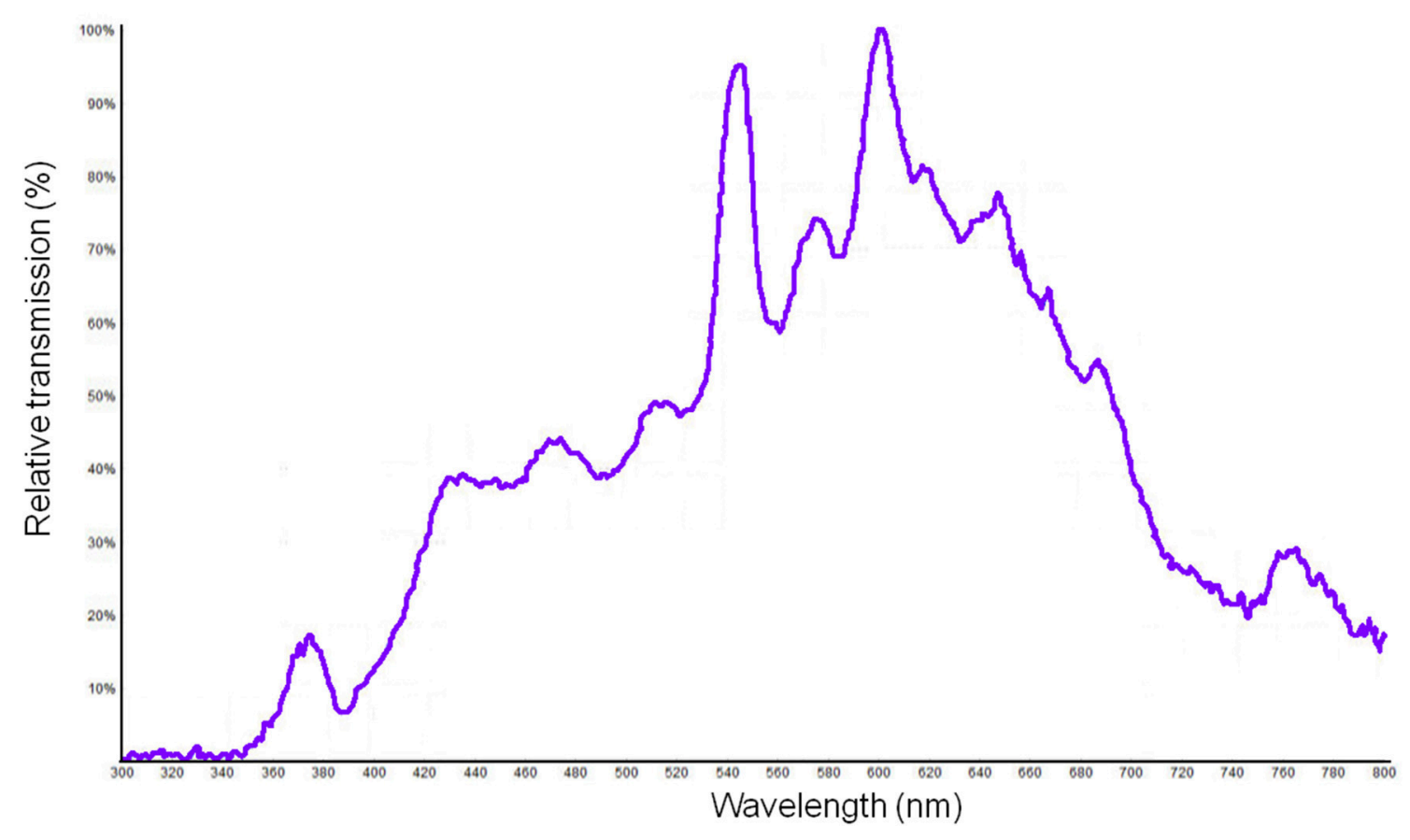

FIGURE 3 | Relative emission curve of the white metal halide (WMH) lamp.

TABLE 1 | Range of minimum photosensitizer concentrations $(\mu \mathrm{g} / \mathrm{ml})$ required to reduce S. aureus growth by $6 \log _{10}$.

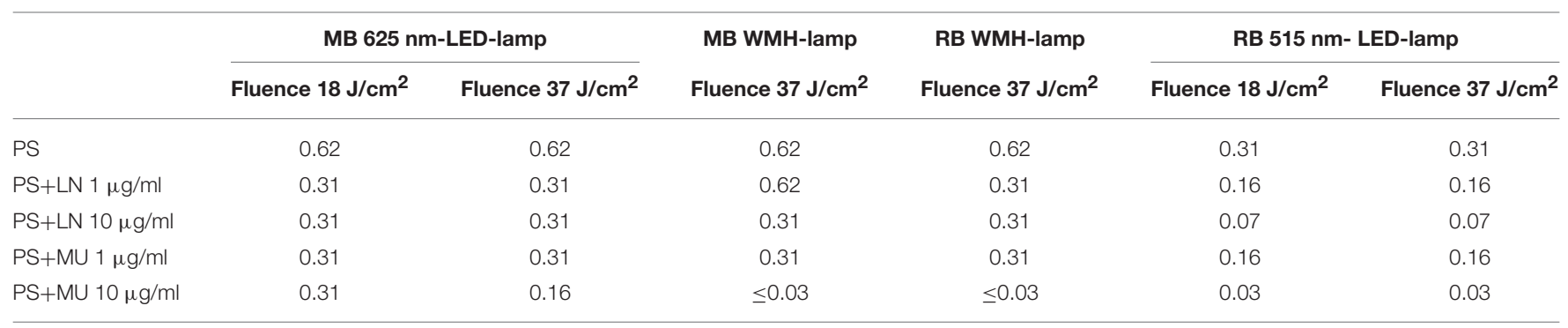

LED, Light-emitting diode; LN, linezolid; MB, methylene blue; MU, mupirocin; PS, photosensitizer; RB, rose bengal; WMH: white metal halide.

The cumulative effect of antibiotic alone and irradiation equated to a reduction in the number of $\mathrm{CFU} / \mathrm{ml}$ of $<0.5 \log _{10}$ (Figures 4, 5).

\section{DISCUSSION}

The present study demonstrates that the combination of MU or LN with MB-aPDT or RB-aPDT exerts a synergistic bactericidal effect against $S$. aureus in vitro. By combining antibiotic with aPDT, the bactericidal effect produced by aPDT alone can be achieved using a much lower photodynamic dose (i.e., lower photosensitizer concentration or lower fluence). Our findings suggest that results obtained with aPDT could be markedly improved by combining this treatment modality with classical antibiotic treatment.

The antimicrobial agents ampicillin, gentamicin, and vancomycin have been previously shown to increase the sensitivity of Enterococcus faecium to aPDT, using $\mathrm{MB}$ as a photosensitizer (Chibebe Junior et al., 2013). Similarly, gentamicin increases the efficacy of aPDT with 5-ALA against S. aureus biofilms (Barra et al., 2015). The combination of vancomycin and aPDT using cationic porphyrins is also highly effective against S. aureus biofilms (Provenza et al., 2009). By contrast, Tanaka and coworkers found that both $\mathrm{LN}$ and vancomycin decrease the therapeutic effect of MB-aPDT in a murine model of MRSA bacterial arthritis (Tanaka et al., 2013). They hypothesized that in that mouse model aPDT may stimulate antibacterial neutrophil activity, rather than actively killing bacteria, and proposed that $\mathrm{LN}$ and vancomycin may inhibit the activation of inflammatory cytokines without eradicating the bacteria, thereby limiting the effect of aPDT. In our study, the combination of LN and MB-aPDT or RBaPDT resulted in a synergistic bactericidal effect on a S. aureus in suspension. To our knowledge, this study is the first to investigate the effect of combining MU antibiotic treatment with aPDT, and demonstrates that the greatest synergistic effect is obtained with 

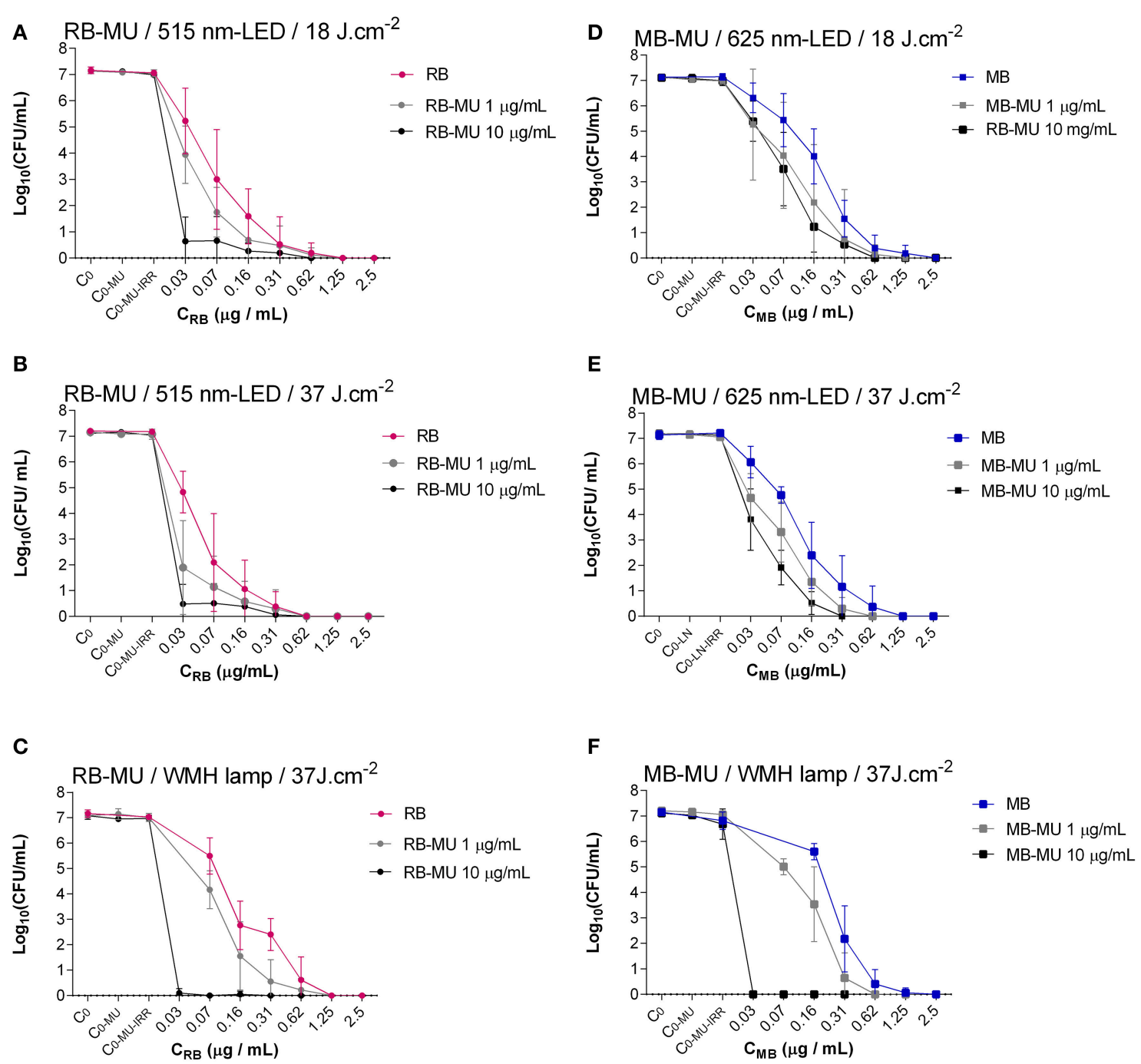

FIGURE 4 | Photoinactivation of S. aureus using different concentrations of RB (left) or MB (right) combined with MU treatment. (A,D), Constant fluence of $18 \mathrm{~J} / \mathrm{cm}^{2}$ with LED lamp; (B,E), constant fluence of $37 \mathrm{~J} / \mathrm{cm}^{2}$ with LED lamp; (C,F), constant fluence of $37 \mathrm{~J} / \mathrm{cm}^{2}$ with WMH lamp. $\mathrm{C}_{0}$, Control of inoculum (Without photosensitizer, without antibiotic, without irradiation); $\mathrm{C}_{0-\mathrm{MU}}$, Control of antibiotic (Without photosensitizer, with antibiotic, without irradiation); $\mathrm{C}_{0-\mathrm{MU}-\mathrm{IRR}}$, Control of irradiation -added to the effect of antibiotic-(Without photosensitizer, with antibiotic, with irradiation).

$\mathrm{MU}+\mathrm{aPDT}$ combination, particularly when RB is used as a photosensitizer. Furthermore, to the best of our knowledge this is the first study to investigate the effects of combining antibiotics with aPDT using RB as the photosensitizer.

The effectiveness of RB-aPDT against $S$. aureus (Kato et al., 2012; Nakonechny et al., 2013), including MRSA (Guo et al., 2010), has been previously demonstrated, with green light (Guo et al., 2010) producing a greater reduction in bacterial growth than white light (Kato et al., 2012; Nakonechny et al., 2013). These results are in good agreement with those of the present study. We found that the concentration of $\mathrm{RB}$ required to reduce bacterial growth by $6 \log _{10}$ using the WMH light $(0.6 \mathrm{ug} / \mathrm{ml})$ was double that required when green light was used $(0.3 \mathrm{ug} / \mathrm{ml})$. A list of studies investigating the effect of RB-aPDT on S.aureus is provided in Table 2 .
Previous studies have demonstrated the in vitro efficacy of MB-aPDT against both S. aureus and MRSA (Yow et al., 2011; Kashef et al., 2012; Tanaka et al., 2012) using white light lamps (Zeina et al., 2001; Nakonechny et al., 2013) and red LED lamps (Yow et al., 2011; Huang et al., 2012; Kashef et al., 2012; Vecchio et al., 2015). Although we used higher fluences and lower MB concentrations, our findings are in good agreement with those of previous studies, as shown in Table 3 (Yow et al., 2011; Huang et al., 2012; Nakonechny et al., 2013; Vecchio et al., 2015).

Selecting a light source with an emission spectrum that corresponds to the absorption spectrum of the photosensitizer should theoretically result in greater efficacy (Calzavara-Pinton et al., 2007). We observed efficient excitation of photosensitizers using either a LED lamp with an appropriate emission $\lambda$ for each of the 2 photosensitizers tested, or a WHM light that 

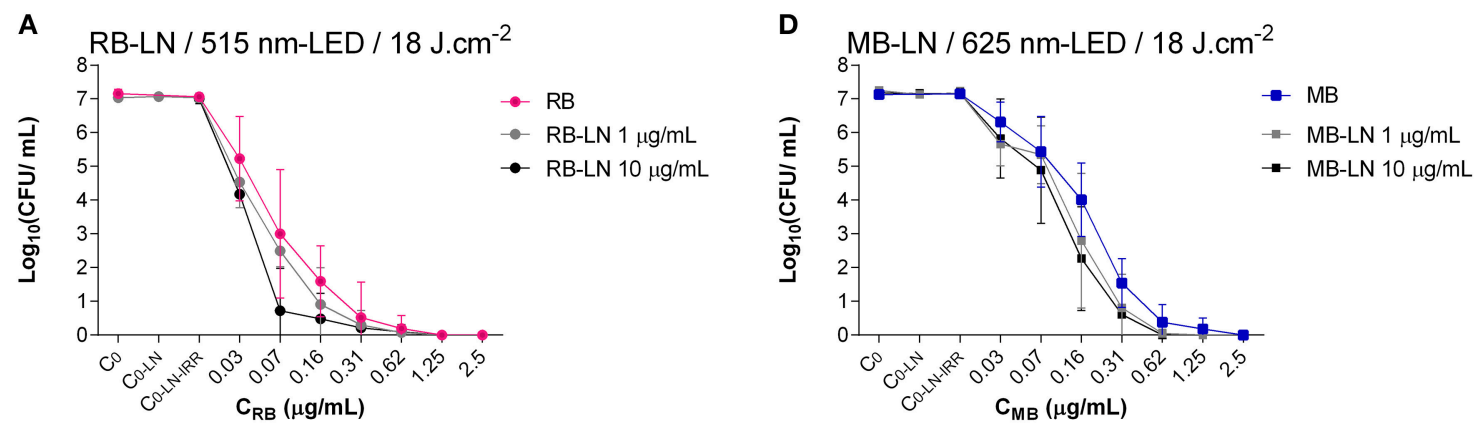

B

E
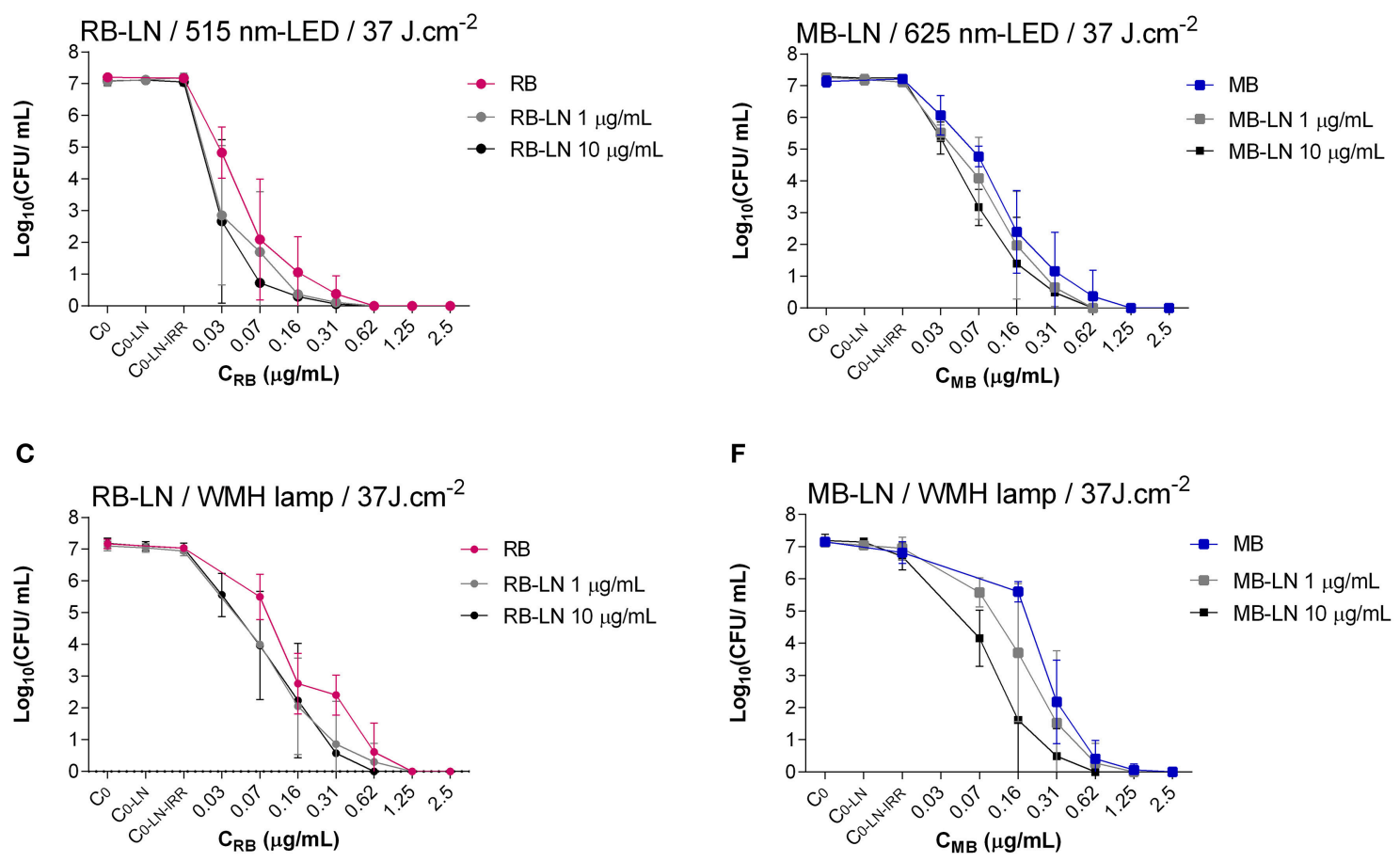

FIGURE 5 | Photoinactivation of S. aureus with different concentrations of RB (left) or MB (right) combined with LN treatment. (A,D) Constant fluence of $18 \mathrm{~J} / \mathrm{cm}^{2}$ with LED lamp; (B,E), constant fluence of $37 \mathrm{~J} / \mathrm{cm}^{2}$ with LED lamp; (C,F), constant fluence of $37 \mathrm{~J} / \mathrm{cm}^{2}$ with WMH lamp. $\mathrm{C}_{0}$, Control of inoculum (Without photosensitizer, without antibiotic, without irradiation); $\mathrm{C}_{0}-\mathrm{LN}$, Control of antibiotic (Without photosensitizer, with antibiotic, without irradiation); $\mathrm{C}_{0-\mathrm{LN}-I R R}$, Control of irradiation -added to the effect of antibiotic-(Without photosensitizer, with antibiotic, with irradiation).

TABLE 2 | Summary of studies of the in vitro efficacy of RB-aPDT on S.aureus.

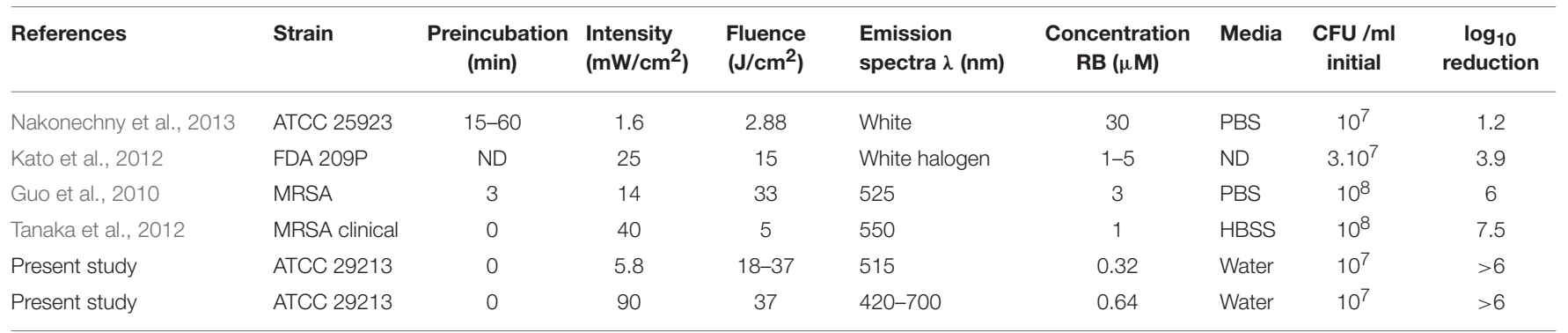

$R B$, Rose bengal. 
TABLE 3 | Summary of studies of the in vitro efficacy of MB-aPDT on S. aureus.

\begin{tabular}{|c|c|c|c|c|c|c|c|c|c|}
\hline References & Strain & $\begin{array}{l}\text { Preincubation } \\
\text { (min) }\end{array}$ & $\begin{array}{l}\text { Intensity } \\
\left(\mathrm{mW} / \mathrm{cm}^{2}\right)\end{array}$ & $\begin{array}{l}\text { Fluence } \\
\left(\mathrm{J} / \mathrm{cm}^{2}\right)\end{array}$ & $\begin{array}{c}\text { Emission } \\
\text { spectra } \lambda(\mathrm{nm})\end{array}$ & $\begin{array}{c}\text { Concentration } \\
\text { MB }(\mu \mathrm{M})\end{array}$ & Media & $\begin{array}{l}\text { CFU/ml } \\
\text { initial }\end{array}$ & $\begin{array}{l}\log _{10} \\
\text { reduction }\end{array}$ \\
\hline Huang et al., 2012 & $8325-4$ & 30 & 100 & 8 & 660 & 20 & PBS & $10^{8}$ & 6 \\
\hline Vecchio et al., 2015 & NCTC 8325 & 15 & ND & 5 & 660 & 20 & PBS & $10^{8}$ & 4 \\
\hline Kashef et al., 2012 & ATCC 25923 & 30 & 91 & 163.8 & 660 & 156.32 & PBS & $10^{4}-10^{5}$ & 3.1 \\
\hline Kashef et al., 2012 & MRSA & 30 & 91 & 163.8 & 660 & 156.32 & PBS & $10^{4}-10^{5}$ & 2.2 \\
\hline Yow et al., 2011 & ATCC 25923 & 0 & ND & 30 & 600 & 3 & PBS & $10^{8}$ & 6.5 \\
\hline Yow et al., 2011 & MRSA clinical & 0 & ND & 30 & 600 & 3 & PBS & $10^{8}$ & 7 \\
\hline Tanaka et al., 2012 & MRSA clinical & 0 & 0.040 & 20 & 665 & 100 & HBSS & $10^{8}$ & 6.5 \\
\hline Nakonechny et al., 2013 & ATCC 25923 & 15 & 1.6 & 2.88 & White & 30 & PBS & $10^{6}$ & 6 \\
\hline Zeina et al., 2001 & Oxford & 0 & 42 & 15.12 & $400-700$ & 312.65 & PBS & $10^{8}$ & 5.4 \\
\hline Our study & ATCC 29213 & 0 & 7 & $18-37$ & 625 & 7.6 & water & $10^{7}$ & 6 \\
\hline Our study & ATCC 29213 & 0 & 90 & 37 & $420-700$ & 7.6 & water & $10^{7}$ & 6 \\
\hline
\end{tabular}

MB, Methylene blue.

covers the absorption spectra of most photosensitizers, making aPDT easier to perform and avoiding the need to use a specific lamp for each photosensitizer (Soria-Lozano et al., 2015). PDT using artificial white light has been shown to be as effective and well-tolerated as daylight photodynamic therapy (DL-PDT) for actinic keratosis (O'Gorman et al., 2016). DL-PDT is a new PDT modality in which the photosensitizer is activated by sunlight rather than a lamp (Enk et al., 2015; Gilaberte et al., 2015; Morton et al., 2015). The use of daylight makes the PDT procedure simpler and more efficient (de Berker et al., 2007; Wiegell et al., 2012; Vignion-Dewalle et al., 2015). The results of our experiments using a white light lamp suggest that cutaneous infections caused by $S$. aureus could be treated using daylight-activated aPDT combined with either topical (MU) or systemic (LI) antibiotic treatment. However, it should be borne in mind that the present findings were obtained following in vitro irradiation of cultured microorganisms, and results could differ when deep tissue penetration of light is required.

To our knowledge, this is the first study to investigate the efficacy of several combinations of PDT and antibiotics in the treatment of $S$. aureus. We found that the most efficacious combination was RB-aPDT using green or white light, the photosensitizer RB, and the antibiotic MU. While we did not examine the effects of this approach in vivo or in biofilms, the synergistic effects of aPDT combined with antibiotics described here demonstrate that, at least in a bacterial suspension, the concentration of photosensitizer required to achieve a bactericidal effect is significantly lower than that required with aPDT alone. The main advantage of this combination in terms of clinical application would be a decreased intensity of blue or red staining caused when the photosensitizer is applied to the skin or mucous membranes, making the procedure more cosmetically appealing. Whether this approach would decrease the likelihood of developing antibiotic resistance or overcome existing problems caused by antibiotic-resistant bacteria, as has been proposed (Bartolomeu et al., 2016), remains to be determined.

\section{CONCLUSION}

The combination of the antibiotics MU or LN with aPDT using the photosensitizers $\mathrm{RB}$ or $\mathrm{MB}$ results in a synergistic bactericidal effect on $S$. aureus in vitro.

Combining aPDT with concomitant classical antibiotic treatment may produce better results than those obtained using aPDT alone.

\section{AUTHOR CONTRIBUTIONS}

VP participated in the design of the study, conducted all experiments, performed the figures and drafted the manuscript. AR and YG contributed equally to this work: participated in the design of the study, in the analysis and interpretation of data for the work and drafted the manuscript. LP and VL conducted some experiments and helped to draft the manuscript. IG and SB checked our results and have contributed to the interpretation of data for the work and to the resolution of biofilms questions and in the discussion of the final manuscript because they work with us in the project CTQ 2013-48767-C3-2-R from the Spanish Ministry of Science and Innovation studing the effect of photodynamic therapy on biofilms. SN participated in the design of the study and he revised and corrected the manuscript particularly everything related light parameters. MP revised and corrected the manuscript particularly the background and the discussion. All authors read and approved the final manuscript.

\section{ACKNOWLEDGMENTS}

This work was supported by grant CTQ2013-48767-C3-2-R and CTQ2013-48767-C3-1-R from the Spanish Ministerio de Economía y Competitividad. 


\section{REFERENCES}

Barra, F., Roscetto, E., Soriano, A. A., Vollaro, A., Postiglione, I., Pierantoni, G. M., et al. (2015). Photodynamic and antibiotic therapy in combination to fight biofilms and resistant surface bacterial infections. Int. J. Mol. Sci. 16, 20417-20430. doi: 10.3390/ijms160920417

Bartolomeu, M., Rocha, S., Cunha, Â., Neves, M. G., Faustino, M. A., and Almeida, A. (2016). Effect of photodynamic therapy on the virulence factors of Staphylococcus aureus. Front. Microbiol. 7:267. doi: 10.3389/fmicb.2016.00267

Boucher, H. W., Talbot, G. H., Bradley, J. S., Edwards, J. E., Gilbert, D., Rice, L. B., et al. (2009). Bad bugs, no drugs: no ESKAPE! An Update from the Infectious Diseases Society of America. Clin. Infect. Dis. 48, 1-12. doi: 10.1086/ 595011

Calzavara-Pinton, P. G., Venturini, M., and Sala, R. (2007). Photodynamic therapy: update 2006. Part 1: photochemistry and photobiology. J. Eur. Acad. Dermatol. Venereol. 21, 293-302. doi: 10.1111/j.1468-3083.2006. 01902.x

Cattaneo, D., Orlando, G., Cozzi, V., Cordier, L., Baldelli, S., Merli, S., et al. (2013). Linezolid plasma concentrations and occurrence of drugrelated haematological toxicity in patients withgram-positive infections. Int. J. Antimicrob. Agents 41, 586-589. doi: 10.1016/j.ijantimicag.2013. 02.020

Chibebe Junior, J., Fuchs, B. B., Sabino, C. P., Junqueira, J. C., Jorge, A. O., Ribeiro, M. S., et al. (2013). Photodynamic and antibiotic therapy impair the pathogenesis of Enterococcus faecium in a whole animal insect model. PLoS ONE 8:e55926. doi: 10.1371/journal.pone.0055926

Dai, T., Fuchs, B. B., Coleman, J. J., Prates, R. A., Astrakas, C., St Denis, T. G., et al. (2012). Concepts and principles of photodynamic therapy as an alternative antifungal discovery platform. Front. Microbiol. 3:120. doi: 10.3389/fmicb.2012.00120

de Berker, D., McGregor, J. M., and Hughes, B. R. (2007). Guidelines for the management of Actinic Keratoses. Br. J. Dermatol. 156, 222-230. doi: 10.1111/j.1365-2133.2006.07692.x

Demidova, T. N., and Hamblin, M. R. (2005). Photodynamic inactivation of Bacillus spores, mediated by phenothiazinium dyes. Appl. Environ. Microbiol. 71, 6918-6925. doi: 10.1128/AEM.71.11.6918-6925. 2005

Di Poto, A., Sbarra, M. S., Provenza, G., Visai, L., and Speziale, P. (2009). The effect of photodynamic treatment combined with antibiotic action or host defence mechanisms on Staphylococcus aureus biofilms. Biomaterials 30, 3158-3166. doi: 10.1016/j.biomaterials.2009.02.038

Emori, T. G., and Gaynes, R. P. (1993). An overview of nosocomial infection, including the role of microbiology laboratory. Clin. Microbiol. Rev. 6, 428-442. doi: 10.1128/CMR.6.4.428

Enk, C. D., Nasereddin, A., Alper, R., Dan-Goor, M., Jaffe, C. L., and Wulf, H. C. (2015). Cutaneous leishmaniasis responds to daylight-activated photodynamic therapy: proof of concept for a novel self-administered therapeutic modality. Br. J. Dermatol. 172, 1364-1370. doi: 10.1111/bjd.13490

Gilaberte, Y., Aguilar, M., Almagro, M., Correia, O., Guillén, C., Harto, A., et al. (2015). Spanish-Portuguese consensus statement on use of daylight-mediated photodynamic therapy with methyl aminolevulinate in the treatment of actinic keratosis. Actas Dermosifiliogr. 106, 623-631. doi: 10.1016/j.ad.2015.06.001

Gostev, V. V., Kalinogorskaya, O. S., Popenko, L. N., Chernenkaya, T. V., Naumenko, Z. S., Voroshilova, T. M., et al. (2015). Antibiotic Resistance of MRSA in the Russian Federation. Antibiot Khimioter. 60, 3-9.

Zeina, B., Greenman, J., Purcell, W. M., and Das, B. (2001). Killing of cutaneous microbial species by photodynamic therapy. Br. J. Dermatol. 144, 274-278. doi: 10.1046/j.1365-2133.2001.04013.x

Gu, B., Kelesidis, T., Tsiodras, S., Hindler, J., and Humphries, R. M. (2013). The emerging problem of linezolid-resistant Staphylococcus. J. Antimicrob. Chemother. 68, 4-11. doi: 10.1093/jac/dks354

Guo, Y., Rogelj, S., and Zhang, P. (2010). Rose Bengal-decorated silica nanoparticles as photosensitizers for inactivation of gram-positive bacteria. Nanotechnology 21:065102. doi: 10.1088/0957-4484/21/6/065102

Henderson, B. W., and Dougherty, T. J. (1992). How does photodynamic therapy work? Photochem. Photobiol. 55, 145-157. doi: 10.1111/j.1751-1097.1992.tb04222.x
Huang, L., St Denis, T. G., Xuan, Y., Huang, Y. Y., Tanaka, M., Zadlo, A., et al. (2012). Paradoxical potentiation of methylene blue-mediated antimicrobial photodynamic inactivation by sodium azide: role of ambient oxygen and azide radicals. Free Radic. Biol. Med. 53, 2062-2071. doi: 10.1016/j.freeradbiomed.2012.09.006

Kashef, N., Ravaei Sharif Abadi, G., and Djavid, G. E. (2012). Phototoxicity of phenothiazinium dyes against methicillin-resistant Staphylococcus aureus and multi-drug resistant Escherichia coli. Photodiagnosis Photodyn. Ther. 9, 11-15. doi: 10.1016/j.pdpdt.2011.11.004

Kato, H., Komagoe, K., Nakanishi, Y., Inoue, T., and Katsu, T. (2012). Xanthene dyes induce membrane permeabilization of bacteria and erythrocytes by photoinactivation. Photochem. Photobiol. 88, 423-431. doi: 10.1111/j.1751-1097.2012.01080.x

Larru, B., Gong, W., Vendetti, N., Sullivan, K. V., Localio, R., Zaoutis, T. E., et al. (2016). Bloodstream infections in hospitalized children: epidemiology and antimicrobial susceptibilities. Pediatr. Infect. Dis. J. 35, 507-510. doi: 10.1097/INF.0000000000001057

Livermore, D. M. (2009). Has the era of untreatable infections arrived? J. Antimicrob. Chemother. 64, i29-i36. doi: 10.1093/jac/dkp255

Morton, C. A., Wulf, H. C., Szeimies, R. M., Gilaberte, Y., Basset-Seguin, N., Sotiriou, E., et al. (2015). Practical approach to the use of daylight photodynamic therapy with topical methyl aminolevulinate for actinic keratosis: a European consensus. J. Eur. Acad. Dermatol. Venereol. 29, 1718-1723 doi: $10.1111 /$ jdv.12974

Nakonechny, F., Nisnevitch, M., Nitzan, Y., and Nisnevitch, M. (2013). Sonodynamic excitation of rose bengal for eradication of grampositive and gram-negative bacteria. BioMed Res. Int. 2013:684930. doi: $10.1155 / 2013 / 684930$

O’Gorman, S. M., Clowry, J., Manley, M., McCavana, J., Gray, L., Kavanagh, A., et al. (2016). Artificial white light vs daylight photodynamic therapy for actinic keratoses: a randomized clinical trial. JAMA Dermatol. 152, 638-644. doi: 10.1001/jamadermatol.2015.5436

Orrett, F. A. (2008). The emergence of mupirocin resistance among clinical isolates of methicillin-resistant Staphylococcus aureus in Trinidad: a first report. Jpn. J. Infect. Dis. 61, 107-110.

Orrett, F. A., and Land, M. (2006). Methicillin-resistant Staphylococcus aureus prevalence: current susceptibility patterns in Trinidad. BMC Infect. Dis. 6:83. doi: 10.1186/1471-2334-6-83

Provenza, G., Visai, L., and Speziale, P. (2009). The effect of photodynamic treatment combined with antibiotic action or host defence mechanisms on ibiofilms. Biomaterials 30, 3158-3166. doi: 10.1016/j.biomaterials.2009.02.038

Saderi, H., Owlia, P., and Habibi, M. (2008). Mupirocin resistance among Iranian isolates of Staphylococcus aureus. Med Sci Monit. 14, BR210-3.

Sbarra, M. S., Arciola, C. R., Di Poto, A., Saino, E., Rohde, H., Speziale, P., et al. (2009). The photodynamic effect of tetra-substituted N-methyl-pyridylporphine combined with the action of vancomycin or host defense mechanisms disrupts Staphylococcus epidermidis biofilms. Int. J. Artif. Organs. 32, 574-583.

Soria-Lozano, P., Gilaberte, Y., Paz-Cristobal, M. P., Pérez-Artiaga, L., LampayaPérez, V., Aporta, J., et al. (2015). In vitro effect photodynamic therapy with differents photosensitizers on cariogenic microorganisms. BMC Microbiol. 15:187. doi: 10.1186/s12866-015-0524-3

Tallón, P., Cano, J., Pe-alver, M. C., Pemán, J., and Gobernado, G. (2002). Susceptibility of Staphylococcus aureus isolated from blood to 11 antimicrobial agents and a review of the literature. Rev. Esp. Quimioter. 15, 158-168.

Tanaka, M., Kinoshita, M., Yoshihara, Y., Shinomiya, N., Seki, S., Nemoto, K., et al. (2012). Optimal photosensitizers for photodynamic therapy of infections should kill bacteria but spare neutrophils. Photochem. Photobiol. 88, 227-232. doi: 10.1111/j.1751-1097.2011.01005.x

Tanaka, M., Mroz, P., Dai, T., Huang, L., Morimoto, Y., Kinoshita, M., et al. (2013). Linezolid and vancomycin decrease the therapeutic effect of methylene blue-photodynamic therapy in a mouse model of MRSA bacterial arthritis. Photochem. Photobiol. 89, 679-682. doi: 10.1111/php.12040

Vecchio, D., Gupta, A., Huang, L., Landi, G., Avci, P., Rodas, A., et al. (2015). Bacterial photodynamic inactivation mediated by methylene blue and red light is enhanced by synergistic effect of potassium iodide. Antimicrob. Agents Chemother. 59, 5203-5212. doi: 10.1128/AAC.00019-15 
Vignion-Dewalle, A. S., Betrouni, N., Tylcz, J. B., Vermandel, M., Mortier, L., and Mordon, S. (2015). Comparison of three light doses in the photodynamic treatment of actinic keratosis using mathematical modelling. J. Biomed. Opt. 20:058001. doi: 10.1117/1.JBO.20.5.058001

Wiegell, S. R., Wulf, H. C., Szeimies, R. M., Basset-Seguin, N., Bissonnette, R., Gerritsen, M. J., et al. (2012). Daylight photodynamic therapy for actinic keratosis: an international consensus: International Society for Photodynamic Therapy in Dermatology. J. Eur. Acad. Dermatol. Venereol. 26, 673-679. doi: $10.1111 / j .1468-3083.2011 .04386 . x$

Yow, C. M. N., Fung, K., and Wong, K. C. (2011). Photodynamic inactivation of multi-drug resistant pathogens in Hong Kong. Hong Kong Med. J. 17(Suppl. 2), S24-S28.
Conflict of Interest Statement: The authors declare that the research was conducted in the absence of any commercial or financial relationships that could be construed as a potential conflict of interest.

Copyright (c) 2017 Pérez-Laguna, Pérez-Artiaga, Lampaya-Pérez, García-Luque, Ballesta, Nonell, Paz-Cristobal, Gilaberte and Rezusta. This is an open-access article distributed under the terms of the Creative Commons Attribution License (CC BY). The use, distribution or reproduction in other forums is permitted, provided the original author(s) or licensor are credited and that the original publication in this journal is cited, in accordance with accepted academic practice. No use, distribution or reproduction is permitted which does not comply with these terms. 